Article

\title{
First Captive Breeding Program for the Endangered Pyrenean Sculpin (Cottus hispaniolensis Bacescu-Master, 1964)
}

\author{
Joan Manubens ${ }^{1, *}$, Oriol Comas ${ }^{1}$, Núria Valls ${ }^{1}$ and Lluís Benejam ${ }^{2}$ \\ 1 Associació de Defensa i Estudi de la Fauna i Flora Autòctona (ADEFFA), Camadoca, Santa Maria de Merlès, \\ 08517 Catalonia, Spain; a.adeffa@gmail.com (O.C.); hola@adeffa.cat (N.V.) \\ 2 Aquatic Ecology Group, University of Vic-Central University of Catalonia, Vic, 08500 Catalonia, Spain; \\ lluis.benejam@uvic.cat \\ * Correspondence: joanmanubensgil@gmail.com
}

Received: 28 September 2020; Accepted: 22 October 2020; Published: 24 October 2020

\begin{abstract}
The strong decline of freshwater fish species in Europe implies that further ex-situ conservation plans should be implemented in the near future. The present study reflects our experience with the Pyrenean sculpin (Cottus hispaniolensis Bacescu-Mester, 1964)—a small cottid endemic to the Hispano-French Garona River basin. In recent years, the Spanish Pyrenean sculpin population has reached a limit situation. Because of that, the non-profit association ADEFFA - with support from the public administration-started the first captive breeding program for this species in 2006. Fourteen years later, this study presents the results and evaluates the different steps of the program, with the aim of discussing and improving the ex-situ conservation plans for this and other cold freshwater species. There is a description and a comparison between six consecutive phases during the captive breeding process: nesting behaviour, courtship, egg fixation, parental care (incubation), hatching and survival during juvenile development. The purposes of this project are to: (1) identify the most determining phases for a successful captive breeding; (2) identify the factors that had a major influence to the success of the critical phases; and (3) increase the number of the offspring. This study is based on thirty-three wild individuals collected from Garona River (Val d'Aran, Spanish Pyrenees). During the program, twelve couples spawned in captive conditions, with around 2300 eggs laid. Eight couples bred successfully, with 751 hatched individuals and 608 juveniles reared. The analysis of each step of the captive breeding does not reveal significant differences between phases, so it can be concluded that they are all critical at the same level. In the literature, similar study-cases of captive breeding programs identify incubation and survival phases as the most critical. Consequently, the management made for this project has probably allowed to overcome in part the main impediments described in other similar programs.
\end{abstract}

Keywords: threatened species; conservation planning; climate change; captive breeding; Cottus hispaniolensis

\section{Introduction}

Freshwater ecosystems are some of the most threatened ones in the world. Over 37\% of European freshwater fishes are threatened-which is one of the highest threat levels in any major taxonomic group [1]. Especially the Iberian Peninsula is experiencing a critical conservation status of its ichthyofauna, with $52 \%$ of species now catalogued as critically endangered, endangered or vulnerable, according to the IUCN criteria. This condition is related to a high degree of endemism (among native species, $65 \%$ are endemic to the Iberian Peninsula) and a long history of human impact in these areas $[2,3]$. 
In Europe freshwater species of the genus Cottus (family Cottidae, order Scorpaeniformes) are found in a variety of cold-water habitats such as well-oxygenated headwaters, lakes and channels. They are generally nocturnal and feed on wide variety of benthic invertebrates. The egg-laying period occurs between March and April (when the water temperature rises above $12{ }^{\circ} \mathrm{C}$ ). The eggs are adhesive, laid in a compact clutch on the ceiling of small cavities, so they need gravel or rocky river beds. Females spawn once a year and most individuals spawn for several years. Males guard the eggs until hatching, while they do not feed and may lose $20 \%$ of their body weight [4-6].

Recently, a total of 16 Cottus species have been described in Europe [4,5,7]. Several of these species are endemic of certain river basins and isolated in their particular habitats, as ecological barriers do not allow them to migrate across main rivers [4,5]. These speciation events occurred due to glacial periods [8,9]. These range-restricted species have been reported as endangered during the past few years, mostly due to habitat fragmentation [10-13]. The habitat fragmentation is aggravated by the intense human pressure, with additional threats such as habitat reduction caused by urban and agricultural pollution; water extraction for agriculture and damming; or unnatural flow regimes resulting from flow regulations which meet electrical power demands_often resulting in low water levels, followed by instantaneous high flow regimes $[6,10,11,13]$. This impact has reduced the distribution areas into smaller and isolated populations, which face serious risks such as environmental changes, demographic stochasticity, natural catastrophes and reduced genetic variability. Therefore, the combination of these threats leads to population decline and, eventually, to extinction [14-16].

This study focuses on the Pyrenean sculpin (Cottus hispaniolensis Bacescu-Mester, 1964), a small cottid (up to 100-150 mm, total length) endemic to the Hispano-French Garona River basin and restricted to the southern part of the drainage-in the central part of the Pyrenean mountain range $[4,5]$. This species shows a discontinuous presence along its distribution range [17], with an apparent (but unknown) degree of isolation.

Freyhof \& Kottelat [18] catalogued the Pyrenean sculpin as of Least Concern according to the IUCN guidelines. Afterwards, Doadrio et al. [19] reported an accentuated population decline and proposed to catalogue it as Critically Endangered (B1bc+2bc), which was supported again by Sousa-Santos et al. [13]. The Pyrenean sculpin is included in the Annex II of the European Habitats Directive 92/43/EEC [20] and in the Annex I (for endangered species) of the Spanish National Catalogue of threatened species [21]. In the French Red List, it is included as Data Deficient [6].

During the summer of 2013, there was a devastating flood in the Garona River-caused by heavy rainfall and a big fast snow melt-with an estimated return period (RP) of 30-50 years [22-24]. Changes in the river course and the subsequent arrangement by the machinery led the Pyrenean sculpin populations to a limit situation: only 16 individuals were captured during several samplings along most of the Spanish distribution area in 2014 [17].

The delicate situation of the Pyrenean sculpin has been known for a long time. The Conselh Generau d'Aran (local administration) and the LIFE LimnoPirineus project (NAT/ES/001210) have been working with the species. They have been sampling the population of the Pyrenean sculpin since 2001, in different points all along the Spanish part of the Garona and its tributaries, in order to determine its size, density and trends. Further actions need to be implemented—such as genetic studies [17]. Knaepkens et al. [25] have suggested that in-situ actions are required to increase the population size and range of endangered populations. It is therefore necessary to restore the longitudinal functionality of rivers and to guarantee its dilution capacity, by: improving water management policies-in order to mimic the natural hydrologic regime; improving the connectivity with well-designed fish ladders; and reducing pollution - in order to improve water and ecosystem quality [2,13].

When endangered species are incapable of surviving in their natural habitat despite all the in-situ efforts, and effective alternatives are unavailable in the short term, ex-situ conservation can play a crucial role [26-28]. The strong decline of freshwater fish species implies that further ex-situ conservation plans should be implemented in the near future [2]. However, it is important to underline 
that captive breeding is a last resort and it should not be a long-term conservation strategy which excludes other in-situ actions [26,28-30], because it is typically associated with many limitations such as high economic costs, diseases, adaptation to captivity, relaxation of adaptation, inbreeding and loss of genetic diversity - with consequent inbreeding depression and fitness reduction [26-29,31-33].

In 2006, the non-profit association ADEFFA, with the support from the public administration, started the first captive breeding program for this species in Camadoca wildlife centre (Santa Maria de Merlès, Barcelona). The main purposes of the breeding program were to complete the ex-situ breeding cycle, to maintain a genetic stock, and to study the biology, reproduction and behaviour of the Pyrenean sculpin. Other actions such as habitat restoration, population studies in-situ, environmental education and divulgation were also implemented to complement the breeding program [34].

This study describes the results and the evaluation of fourteen years of captive breeding of the Pyrenean sculpin, as an ex-situ conservation program. It describes and compares six consecutive breeding phases during the breeding period: nesting behaviour, courtship, egg fixation, parental care (incubation), hatching and survival during juvenile development, in order to: (1) detect which one of these phases of the reproductive cycle is most determining with respect to the success of the captive breeding; (2) observe the variation into this critical phase/s and the factors influencing its success; (3) determine key factors that influence the success of the captive breeding and the number of offspring produced; and, finally, (4) develop possible improvements for the critical steps of the ex-situ program. The results of other captive breeding programs with cold freshwater species have shown that the incubation and the juveniles' survival are the most critical phases [35-37]. Therefore, the hypothesis is that these two phases could be the most determining ones to the success of the captive breeding program for the Pyrenean sculpin.

\section{Materials and Methods}

\subsection{Brood-Stock Transportation and Maintenence}

Thirty-three wild samples of Pyrenean sculpin (18 males and 15 females) were collected along the Spanish part of the Garona River (Figure 1) by electrofishing during spring in 2006, 2009, 2014, 2017 and 2018, with the collaboration of the Conselh Generau d'Aran forestry guards. Breeders collected in 2014 were maintained in captivity until 2015 breeding season. Fish total length ranged from $70 \mathrm{~mm}$ to $120 \mathrm{~mm}$ and weight ranged from $9 \mathrm{~g}$ to $26 \mathrm{~g}$ at the time of collection. They were carried in $25 \mathrm{~L}$ plastic tanks with oxygenation, inside isolation boxes, to the fauna conservation centre Camadoca (Santa Maria de Merlès, Barcelona). The care and use of all specimens had complied with local animal welfare laws, with the corresponding administration permissions. The facility counts with two $450 \mathrm{~L}$ rectangular glass tanks for the breeders without direct natural illumination and another $250 \mathrm{~L}$ rectangular glass tank for the juveniles and hatched larvae (rearing tank). Since 2015, there is a new and more efficient facility to improve the maintenance, with four more $250 \mathrm{~L}$ rectangular glass tanks for the breeders and direct natural illumination (from a window). In 2018, the frontal part of these tanks was covered partially in order to reduce the direct illumination from the window. The bottom of all the tanks (except the rearing tank) is covered with a gravel layer. Each tank is provided with stones or curved clay tiles as a substratum on which the fish can hide or make nest to spawn. Before every stocking event, water is changed, all the material is renewed and tanks are cleaned and disinfected.

Each tank counts with mechanic filter system $(50 \mathrm{~L} / \mathrm{h})$, water cooling system equipped with thermostat (except in 2006) and continuous aeration. The rearing tank counts with an external UV-irradiation lamp (without direct contact with the tank). A single $40 \mathrm{~W}$ fluorescent suspended at $20 \mathrm{~cm}$ above the water surface of each tank provides a natural photoperiod (13L:11D). Except in 2006 (when there wasn't cooling system), water temperature is maintained between $8{ }^{\circ} \mathrm{C}$ and $10{ }^{\circ} \mathrm{C}$ for 20-40 days after the stocking. At this time, it is gradually increased to $11^{\circ} \mathrm{C}$. Adults are fed every evening with alive Artemia sp. nauplii, chironomids, tubifex and other freshwater macroinvertebrates ad libitum. Juveniles are first fed with decapsulated Artemia sp. during two weeks approx. 


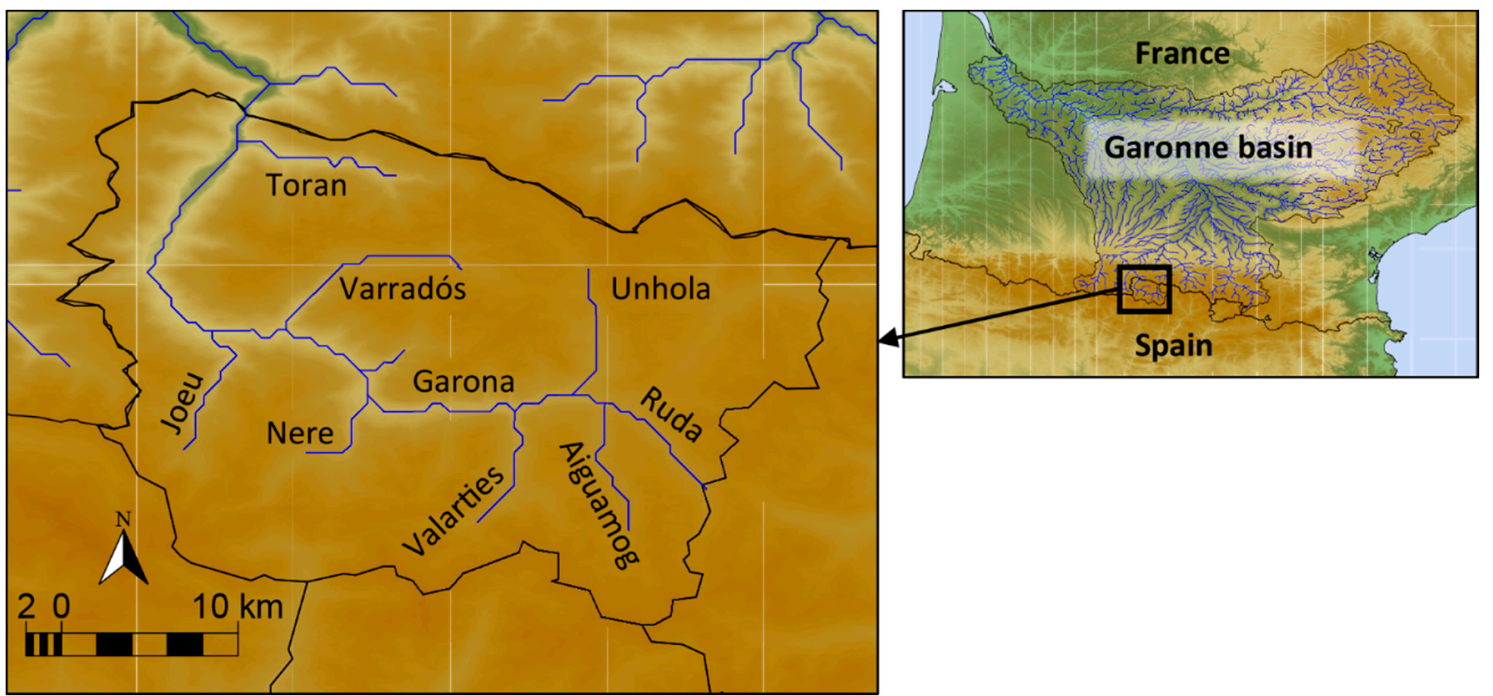

Figure 1. Map of the Garona drainage in Val d'Aran (Catalonia, Spain) and its main tributaries (left) and map of the Garona River basin (right).

\subsection{Reproductive Cycle and Data Analysis}

In order to evaluate which phases of the captive breeding are the most critical (with the objective of improving the breeding techniques effectiveness), the process is divided in six phases ( $1=$ "nesting"; $2=$ "courtship"; $3=$ "fixation"; $4=$ "incubation"; $5=$ "hatching"; $6=$ "survival"). The description of each phase and the success criteria used are attached in Table 1, in concordance with [38]. Each phase is evaluated with success (yes $=1$ ) or failure $($ no $=0$ ), depending on whether the couple finishes the phase successfully. It cannot be either success or failure if the previous phase is failure. Then, the number of couples that succeed in a phase is divided by the initial number of couples (percentage of success from initial couples) and by the number of couples that succeeded in the previous phase (percentage of success from the previous phase). These percentages of the phases considered to be most critical will be analysed.

Table 1. Description of each phase and the success criteria used. The male naturally guards the eggs until the hatching (ca. 30 days), but most times it happens that the clutch is removed from the breeding tank to be put it in the rearing one.

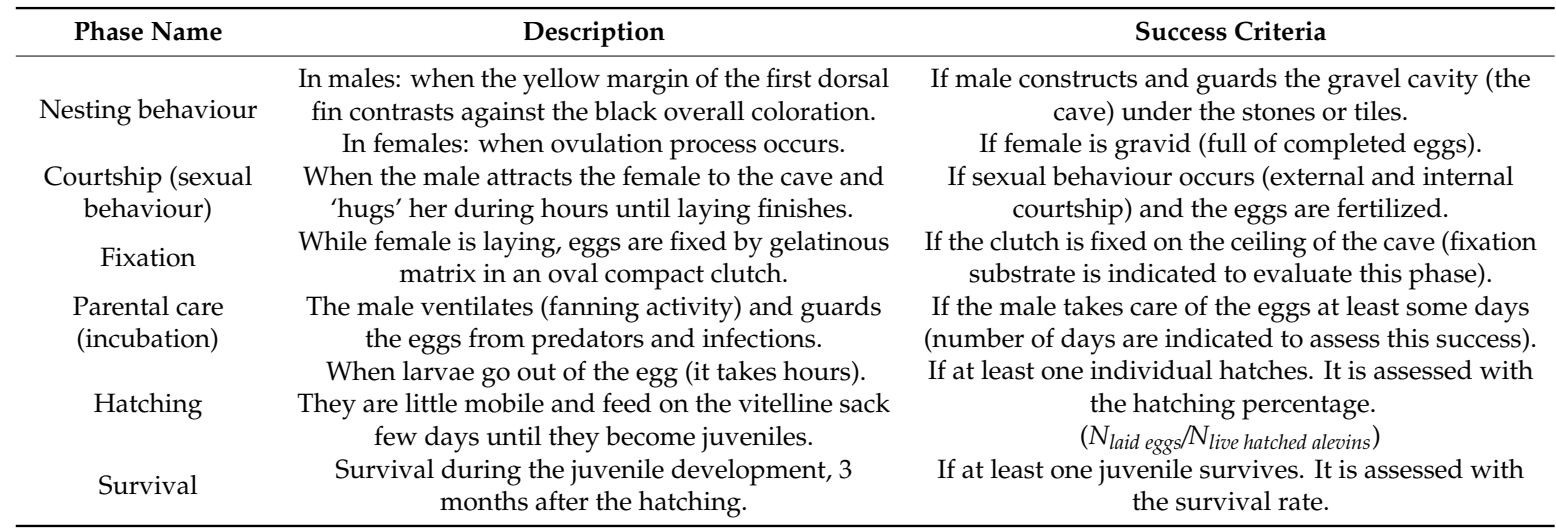

Each couple is also categorized by two additional variables, in order to control its effects upon success in the subsequent analysis and distinguish them from the phases effects upon success: couple type ( 1 = "first year in captivity"; 2 = "one year in captivity at least"; 3 = "born in captivity"; 4 = "combination of 2 and 3") and breeding year (1 = "2006"; 2 = "2009"; 3 = "2014"; 4 = "2015"; $5=$ "2017"; $6=$ "2018"). Then, a logistic regression is performed to test the relation between the binary 
outcome ("Success") and the categorical variables ("Phase", "Type" and "Year") with a Generalized Lineal Model (GLM, family = binomial, link = logit) in Ri383. Four different GLM models are performed to evaluate whether success is related to the different fixed factors (phase, type or year). The first one, considers the interaction between all three factors; the second and the third one, considers the interaction between two of them (the phase with the other two factors); and the last one, considers only the phase. Finally, the most parsimonious model is chosen, by comparing the Akaike Information Criteria (AIC). Significance level for this study is set to $5 \%$.

During the six breeding seasons performed since 2006, twenty-two couples are formed including five individuals (one male and four females) born in captive conditions (Table 2). There are three males present in two couples (14-15, 16-17 and 19-20). Breeders of 2014 are the same individuals in 2015, but any combination of individuals in the couples is the same.

Table 2. Final results summary per year with total number of breeders present in the season and numerical code of each formed couple. Couples 14-15, 16-17 and 19-20 are formed with the same three males and different females. Where $\mathrm{F}=$ female, $\mathrm{M}=$ male. Apart from the success (Yes or No) it is indicated in parentheses the fixation substrate, the number of days during which the male takes care of the eggs, the hatching rate and the survival rate. ${ }^{\dagger}$ Individuals maintained at least one year in captivity.

$\ddagger$ Individuals born in captivity. $\S$ Only female nesting behaviour is considered as success.

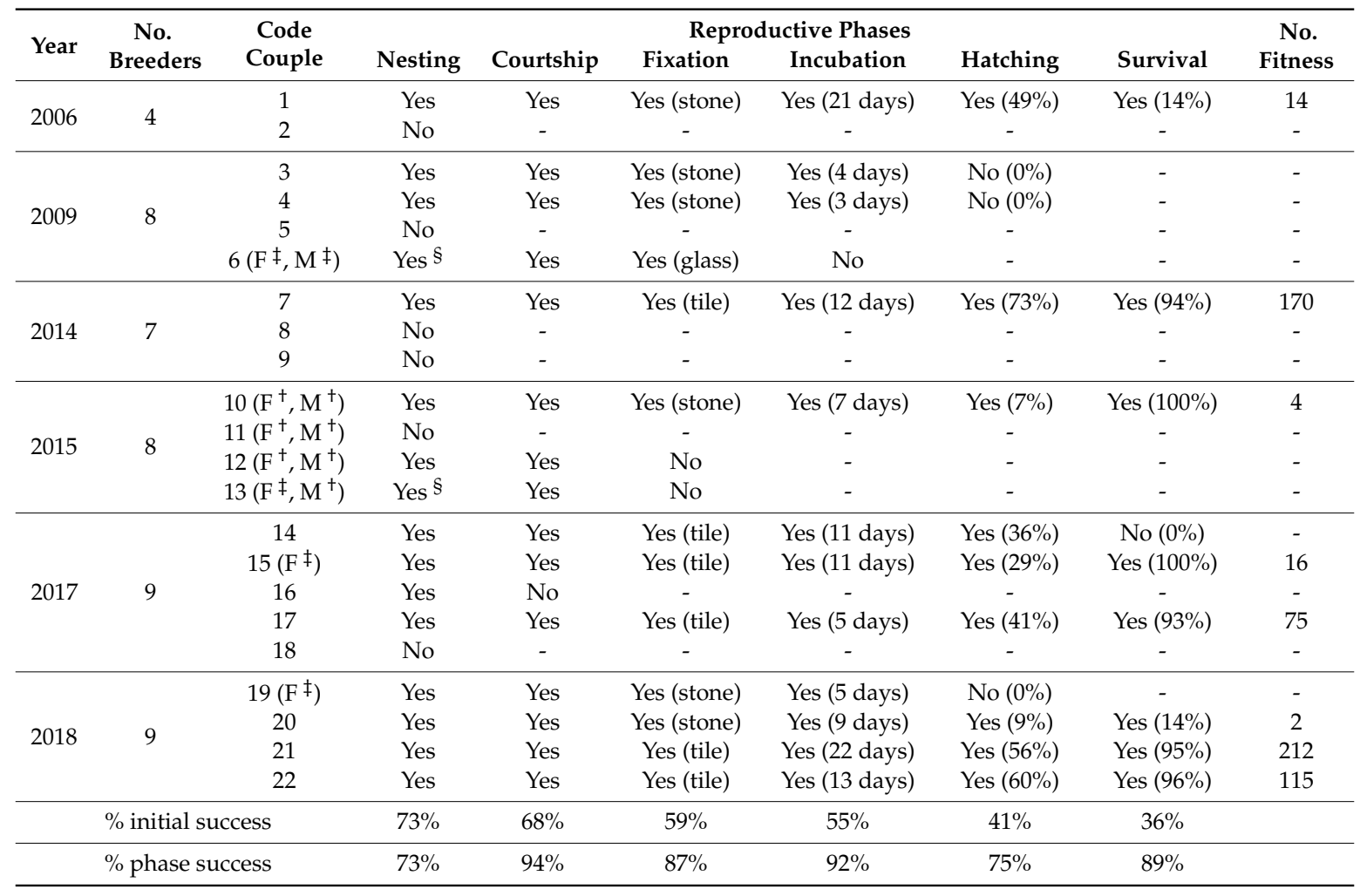

\section{Results}

The results of GLM analysis show that proportion of success and failure is not significantly different among phases of the reproductive cycle (Table 2, Figure 2). Any of the four GLM analysis performed does not show a statistically significant relationship. The best performed model is the one that considers the binary outcome (success) and the effect of different phases ( $p$-value $=0.595$; d.f. $=5$; AIC $=72.91$ ). As it is shown in Table 3, models including the effect of the couple type or the year have a higher AIC value, so it can be considered that the best model has to exclude these effects. Anyway, as no model has a significance level low enough, the success is not significantly different between phases.

Considering that all phases are critical at the same level (no differences among phases), it is analysed the success percent and the variation observed into all of them. The lowest percent observed 
is in nesting behaviour (73\% of the couples), including two couples (6 and 13) in which males did not present nesting behaviour (these couples continued to the next phase and completed it successfully). So, nesting behaviour is observed only in 27 breeders from the 45 present in the program (60\%). On the other hand, $94 \%$ of the couples with success in the first step go on courtship and spawn-the higher percent observed. Only couple 16 failed in this phase (the female laid the clutch without interaction with the male). During 2017 and 2018, there were three males that spawned with two females (Table 2).

Egg fixation was completed in $87 \%$ of the couples in the last step: six fixed the clutch on the stone, six on a tile and one on the glass (couple 6). Couple 13 did not fix it. Female of couple 12 died in this phase without laying. The death cause determined in the necropsy was an ovarian obstruction. $92 \%$ of the fixed clutches were incubated at least few days for the male (parental care). Only two clutches (couple 1 and 21) were incubated until the hatching and the other ten were situated in controlled conditions (in rearing tanks) at 5-13 days after fixation. The second lowest percent is observed in hatching, with $75 \%$ of success of the incubated clutches. Moreover, the hatching rate is very low many times (with a reduced number of hatched larvae). Survival during juvenile development is a success $89 \%$ of the times, with only one failure.

From the eight couples that had brood with success, only four $(7,17,21$ and 22) had reared a considerable number of juveniles. In 2006 (couple 1), there was high mortality due to an infection. The diagnostic analysis_-both of breeders and eggs_carried out in 2006 by doctor Francesc Padrós (Servei de Diagnòstic Patològic de Peixos, UAB) shows that infections during parental care were caused by fungus of the Saprolegnia genus. During the rearing in 2006, an Ichthyophthirius multifiliis infection (white spot disease) was also detected. Since 2015, it is observed that couples situated in the new facilities did not succeeded $(11,12,13,18$ and 19) or had the lowest fitness number (10 and 20).

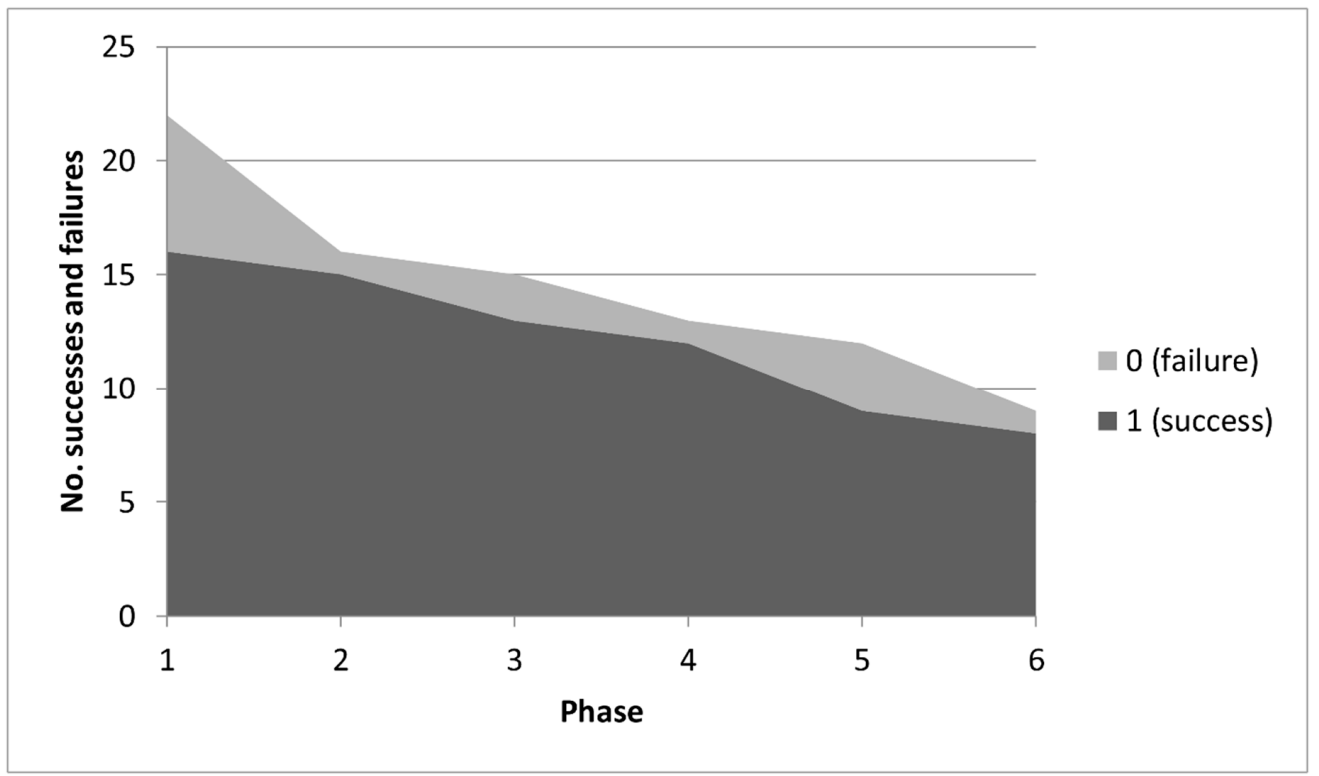

Figure 2. Number of successes (1) and failures (0) in each phase $(1=$ "nesting"; 2 = "courtship"; $3=$ "fixation"; 4 = "incubation"; 5 = "hatching"; 6 = "survival").

Table 3. Results of the performed GLM analysis, with the factors considered for each model, its $p$-value (from a Chi square test), its freedom degrees and its AIC value.

\begin{tabular}{lccc}
\hline \multicolumn{1}{c}{ Model } & $\boldsymbol{p}$-Value & d.f. & AIC \\
\hline Exit $\sim$ Phase + Type + Year & 0.442 & 12 & 82.232 \\
Exit $\sim$ Phase + Type & 0.817 & 8 & 77.976 \\
Exit $\sim$ Phase + Year & 0.769 & 9 & 79.094 \\
Exit $\sim$ Phase & 0.595 & 5 & 72.913 \\
\hline
\end{tabular}


As general results of the breeding program, twelve couples spawned in ten nests with around 2300 eggs laid (mean $=212 ; \mathrm{SD}=118$ ), 751 individuals hatched and 608 juveniles reared. Individuals (juveniles and breeders) of the captive breeding seasons of 2014, 2015 and 2017 were released in different points along the Garona River and its tributaries in collaboration with the LIFE LimnoPirineus project (NAT/ES/001210), a Fecsa ENDESA project and the Conselh Generau d'Aran, in order to support declining populations. There was no post-releasing monitoring program.

\section{Discussion}

As significant differences on the success among phases cannot be determined, the conclusion is that there is no phase more related to success than others. However, in most of the captive breeding programs with cold freshwater species, it is widely known that incubation and juveniles' survival are the most critical phases on its management. This is the case of the well-known salmonids hatcheries [35,39-41]. In the same way, it is also observed in little literature on the ex-situ breeding of the genus Cottus [36,37]. A comparison between the bibliography study-cases and results obtained during this project, leads us to discuss possible success/failure causes, factors that influence success and possible improvements for each phase. The aim is to improve program's management efficacy and finally to collaborate with the species conservation.

\subsection{Analysis of Variation into Phases}

Referring to nesting behaviour, factors that cause differences between couples are unknown. They may be intrinsic factors to the funding individuals (age, size, sexual maturity, life history, etc.) or they may also be factors related to the species' reproductive behaviour (social behaviour, sex ratio, relative size, etc.) —all of them related to mating success in behaviour studies [42-46], so specific behaviour studies (ex-situ and in-situ) should be developed in order to improve captive breeding effectiveness [47]. However, it is observed that there is a limiting factor in this step. The number of gravid females marks the number of couples that can breed, as far as one male can breed with more than one female. For that reason, it would be recommendable to increase the ratio of females per male in the event that there are more females than males in the brood-stock or if males do not present nesting behaviour. The female of the only couple that failed during courtship (couple 16) was bigger than the male, so relative size could be taken into account in future behaviour studies (also suggested by Brown [48] and Bisazza and Marconato [42]). Fixation is probably related to the type of breeders and the time during which they are maintained in captivity, as far as the female of couple 12 did not spawn the previous year (probably due to the ovarian obstruction). Fixation success is also probably related to behaviour, because when males failed in the first step, this phase was never completed correctly (if the clutch was fixed, it was fixed on the glass). Until further behavioural studies still lack, these types of breeders in the program should be avoided. However, the rate of couples that finally fixed the egg-laying (50\%) is considerably higher than the $20 \%$ described in Piccinini et al. [37].

When fixation is completed properly, parental care also succeeds (except couple 6, commented above). Even though, success and quality of successive phases indicate that major problems occur during parental care, due to stress and infections. For its importance, those key factors will be discussed latter in detail. This tendency during parental care—as said before-coincides with problems described in the two study-cases of Cottus species breeding. However, they describe this phase as critical, together with survival-a phase described as successful in the present study. There is only one case in which this phase failed (couple 14), due to a human error in the maintaining. White spot disease problem was practically solved during the following breeding seasons-as the results show-working on the same key factors affecting incubation discussed below. In fact, after 2006, survival is considerably higher comparing with Vught et al. [36]. They describe problems in intensively larvae rearing with tanks. 


\subsection{Key Factors Affecting Success}

There are some principal factors considered to be important for the success of the captive program that have influenced its development. These factors are stress, infections, type of breeders and time during which they are maintained in captivity.

It is well-known that stress negatively affects captive breeding [49]. During the first season of the program, remarkable territorial behaviours with aggressivity between males were observed. In order to avoid these stress inputs, since 2006, males are situated in different tanks during breeding period. It is also important to minimize noise in facilities and handling during all breeding phases. During 2009, some stress factors that could be related to the breeding failure were observed (illumination and noise due to an extensive monitoring with research and education purpose). Moreover, there are many factors such as illumination conditions that have to be considered as stress factors affecting reproduction, as indicate Raghavan et al. [50]. In that way, some of the differences between facilities (such as background coloration, illumination type or intensity) could affect reproduction success, as observed with couples situated in the new facilities. In fact, with a little modification done during 2018 by reducing the impact of overall illumination inside tanks, an improvement in the couple's behaviour situated there (19 and 20) was noted. Although it has to be studied in detail, any relation with smaller tank sizes in the new facilities could be discarded, because other breeding programs such as Vught et al. [36] describe a much larger brood fish density per tank.

Saprolegnia sp. infection is the main cause of problems in the incubation of several captive breeding programs and hatcheries, and it has a direct effect in their success [35,37,39-41]. The male Pyrenean sculpin naturally takes care of the clutch in order to protect it from fungal infections, but their appearance is still inevitable. With the management developed, there are three key factors used to control its expansion. The first one is temperature. In the first year, when there were not coolers, the water temperature was higher during summer, rising at $16{ }^{\circ} \mathrm{C}$-when average temperature does not reach $11^{\circ} \mathrm{C}$ during June in Garona River. Coldwater fish are more resistant to infection at lower temperatures [40]. Conversely, higher temperatures increase Saprolegnia's growth rate [39,51] and favour rapid appearance of fungus while incubating. This can be prevented by maintaining temperature at a relatively low level (considering $11^{\circ} \mathrm{C}$ as optimum for that species). The second key factor is feeding. High level of organic particles and nitrogenous waste in the water may predispose the fish to saprolegniasis [40] and reduce efficiency of disease treatments [52]. Although it is important to feed with organisms similar to the ones that we find in the species natural habitat [29], feeding with organisms from totally different environments may be safer to prevent infections, especially during incubation. It has been shown that high salinity prevents saprolegniasis $[40,53]$ and withe spot disease [54], which could imply that the Artemia sp. is a less probable vector. For that reason, since 2009, during critical periods, we feed exclusively with Artemia sp. Finally, the third key factor: the number of days and the kind of treatment during incubation in controlled conditions (artificial incubation) are probably highly related to the clutch degree of affectation. It has been observed in some occasions (e.g., couple 14 and 15) that if the male incubates during a longer time, the number of viable eggs can be considerably reduced due to a longer exposition to infection. This situation may be also related to filial cannibalism [55]. Otherwise, when the infection is detected in its start (e.g., couple 17) it can be successfully stopped with antifungal treatments in controlled conditions [40,52]. Although the risk of manipulation, infections have been controlled in a more efficient way by removing the clutch from the breeding tank and putting it in the rearing tank in controlled conditions (with also different antifungal treatments, not tested in this study).

The last factor to discuss is the captive breeding method employed. During the captive program, it was observed that captive born females could breed successfully, and wild breeders could be maintained (with breed success as well) more than a year in captivity. However, in order to avoid problems related to captivity, it is important to choose a qualitatively and quantitatively appropriate number of breeders. Thus, the genetic diversity of the captive stock can be maximized [56,57]. It is also important to consider population genetics structure (variability within and between populations), 
with the aim of maintaining offspring genetic variability [2,29]. Supportive breeding method is based on the introduction of new genotypes that increase variability and fitness $[33,58]$. This method raises the demographic size in the post-releasing censuses, but it may result in genetic risks which would also imply problems in terms of fitness reduction if we do not work with some important parameters [10]. In addition, captive populations are frequently established when wild populations of the species are at risk or have already suffered significant reductions in population size, which limits the number of individuals that can be collected, with a small fraction of the genetic diversity [59]. In fact, in some cases, it is not possible to achieve a level of genetic diversity high enough to obtain a self-sufficient captive population without compromising wild populations [60]. In such a case, it is fundamental to choose the most appropriate method of intervention [33].

With the aim to avoid the accumulation of all these problems related to the conditions in captivity over time and to reduce the cost of this complex maintenance, as well as to reduce the risk of accidents (like the one of the death female in 2015), it is recommendable to opt for a system that reduces the duration of the breeding period — as pointed out by Philippart [29]—with wild adults that are sexually mature and that have been collected just before or during the reproduction period. Besides, considering the limited number of individuals of the species of study (due to threat level and the current situation of the population), it could be positive to return both adults and offspring to wild population after the breeding (as has been done in 2017 and 2018). Thus, the total number of breeders of the breeding program will progressively increase over the necessary seasons and it will not have too much impact on the current population.

Precisely, due to this limitation, it has been impossible to carry out replies or different treatments of the factors previously discussed. It has been done this way to avoid risks for breeders and offspring. When the species status improves, it will be possible to develop experimental designs that better explain the influence of the different factors, and it would underline possible differences between phases (that are not significant in the current model).

\section{Conclusions}

It has not been possible to: (1) determine the critical phases of the reproductive cycle under captive conditions - as the expected differences between phases are not significant. Despite that fact, (2) observing variation into phases, many factors that might be related to its success are detected-such as the ratio of females per male, relative size between individuals of the couple and proper courtship. Avoiding stress factors (by reducing illumination and noise); controlling infections by keeping temperature at $11{ }^{\circ} \mathrm{C}$ with coolers, by providing accurate feeding (e.g., Artemia sp.) during critical periods, and by incubating artificially as soon as diseases appear; and reducing as much as possible the period in captivity of the brood-stock and offspring are (3) described as key factors determining breeding success and number of offspring produced. Working upon the factors as soon as they have been detected (improving progressively the program) has probably (4) allowed to overcome main impediments of the most critical steps of the reproductive cycle described in other similar programs. It is true that it has been impossible to carry out replies or different treatments of the factors previously discussed. When the species status improves, it will be possible to develop experimental designs that better explain the influence of the different factors, and it would underline the possible differences between phases (that are not significant in the current model). So, as a general conclusion, the initial aim of the captive breeding program (i.e., to complete the ex-situ breeding cycle) is accomplished with encouraging results in fishes' maintenance, that may be a little step forward for the captive breeding of all endangered Cottus species and its long-term conservation.

Author Contributions: Conceptualization, J.M., O.C., N.V. and L.B.; Data curation, J.M., O.C. and N.V.; Formal analysis, J.M. and L.B.; Funding acquisition, O.C. and N.V.; Investigation, J.N. and L.B.; Methodology, J.M., O.C., N.V. and L.B.; Project administration, O.C. and N.V.; Resources, O.C. and N.V.; Software, J.M.; Supervision, O.C., N.V. and L.B.; Validation, O.C., N.V. and L.B.; Visualization, O.C., N.V. and L.B.; Writing-original draft, J.M.; Writing-review \& editing, J.M. All authors have read and agreed to the published version of the manuscript. 
Funding: Financial support was provided by Fundación Biodiversidad del Ministerio para la Transición Ecológica, grant number FBCA2015CCHMT and FBCA2018CCHGP; Fundació Zoo de Barcelona, grant number BPZB2015CCH; and Obra Social "la Caixa”, grant number OSC2018CEAC.

Acknowledgments: This project has been possible thanks to I. Afonso (Biodiversity Service, Conselh Generau d'Aran); rural guards from Vall d'Aran, who collaborated with the broodstock collection; rural guards from Catalunya Central (particularly to D. Flores); technicians from the Servei de Fauna of the Departament de Territori i Sostenibilitat of the Generalitat de Catalunya; and finally, to F. Padrós (UAB), for his assessment and his pathologic reports. We are also grateful for the collaboration of E. Valbuena-Ureña, J. Mainé, M. Vilaró, J. Casas, S. Arjó, J. Sañé, Q. Pou, M. Ventura, and X. Bayer, P. Guasch, J. Guasch and C. Guasch from Estudi Divulgació Natura (EDN).

Conflicts of Interest: The authors declare no conflict of interest. The funders had no role in the design of the study; in the collection, analyses or interpretation of data; in the writing of the manuscript, or in the decision to publish the results.

\section{References}

1. Freyhof, J.; Brooks, E. European Red List of Freshwater Fishes; Publications office of the European Union: Luxembourg, 2011.

2. Maceda-Veiga, A. Towards the conservation of freshwater fish: Iberian Rivers as an example of threats and management practices. Rev. Fish Biol. Fish. 2013, 23, 1-22. [CrossRef]

3. Miranda, R.; Pino-Del-Carpio, A. Analysing freshwater fish biodiversity records and respective conservation areas in Spain. J. Appl. Ichthyol. 2016, 32, 240-248. [CrossRef]

4. Freyhof, J.; Kottelat, M.; Nolte, A. Taxonomic diversity of European Cottus with description of eight new species (Teleostei: Cottidae). Ichthyol. Explor. Freshw. 2005, 16, 107-172.

5. Kottelat, M.; Freyhof, J. Handbook of European Freshwater Fishes; Kottelat: Cornol, Switzerland; Cornol and Freyhof: Berlin, Germany, 2007.

6. Keith, P.; Persat, H.; Feunteun, É.; Allardi, J. Les Poissons d'eau douce de France. Collection Inventaires $\mathcal{E}$ Biodiversité; Biotope: Mèze, France, 2011.

7. Sideleva, V.G. A new sculpin species Cottus sabaudicus sp. nova (Scorpaeniformes: Cottidae) from the Savoy district, France. J. Ichthyol. 2009, 49, 209-214. [CrossRef]

8. Englbrecht, C.C.; Freyhof, J.; Nolte, A.; Rassmann, K.; Schliewen, U.; Tautz, D. Phylogeography of the bullhead Cottus gobio (Pisces: Teleostei: Cottidae) suggests a pre-Pleistocene origin of the major central European populations. Mol. Ecol. 2000, 9, 709-722. [CrossRef]

9. Volckaert, F.A.M.; Hänfling, B.; Hellemans, B.; Carvalho, G.R. Timing of the population dynamics of bullheadCottus gobio (Teleostei: Cottidae) during the Pleistocene. J. Evol. Biol. 2002, 15, 930-944. [CrossRef]

10. Knaepkens, G.; Baekelandt, K.; Eens, M. Assessment of the movement behaviour of the bullhead (Cottus gobio), an endangered European freshwater fish. Anim. Biol. 2005, 55, 219-226. [CrossRef]

11. Petrova Uzunova, E. Assessment of the conservation status of endemic sculpin Cottus haemusi (Cottidae) in the river Vit (Danube Tributary), northwest Bulgaria. Knowl. Managt. Aquatic Ecosyst. 2011, 403, 10. [CrossRef]

12. Sousa-Santos, M.; Robalo, J.I.; Pereira, A.; Doadrio, I. Threatened fishes of the world: Cottus aturi Freyhof, Kottelat and Nolte 2005 (Cottidae). Croat. J. Fish. 2014, 72, 130-131. [CrossRef]

13. Sousa-Santos, M.; Robalo, J.I.; Pereira, A.; Doadrio, I. Threatened fishes of the world: Cottus hispaniolensis Bacescu-Mester, 1964 (Cottidae). Croat. J. Fish. 2014, 72, 132-133. [CrossRef]

14. Shaffer, M.L. Minimum Population Sizes for Species Conservation. BioScience 1981, 31, 131-134. [CrossRef]

15. Meffe, G.K.; Carroll, C.R. Principles of Conservation Biology; Sinauer Associates: Sunderland, MA, USA, 1997.

16. IUCN/SCC. IUCN Species Survival Commission Guidelines on the Use of Ex Situ Management for Species Conservation: Version 2.0; IUCN Species Survival Commission: Gland, Switzerland, 2014.

17. Rocaspana, R.; Aparicio, E. Population trends and current status of the endangered Pyrenean sculpin Cottus hispaniolensis in the Spanish part of the Garonne drainage. Know. Manag. Aquat. Ecosyst. 2017, 25. [CrossRef]

18. Freyhof, J.; Kottelat, M. Cottus Hispaniolensis. The IUCN Red List of Threatened Species 2008. Available online: https://www.iucnredlist.org/species/135573/4149912 (accessed on 19 March 2020).

19. Doadrio, I.; Perea, S.; Garzón-Heydt, P.; González, J. Ictiofauna continental española. Bases para su seguimiento; DG Medio Natural y Política Forestal. MARM: Madrid, Spain, 2011. 
20. European Commission. Council Directive 92/43/EEC of 21 May 1992 on the conservation of natural habitats and of wild fauna and flora. Off. J. Eur. Union 1992, L 206, 7-50.

21. Gobierno de España, Ministerio de Medio Ambiente, y Medio Rural y Marino. Real Decreto 139/2011, de 4 de febrero, para el desarrollo del Listado de Especies Silvestres en Régimen de Protección Especial y del Catálogo Español de Especies Amenazadas. BOE 2011, 46, 20912-20951.

22. Pineda, N.; Prohom, M.; Serra, A.; Martí, G.; Garcia, C.; Velasco, E.; Gracia, A. Causes que van provocar la riuada a la Val d'Aran el 18 de juny 2013. In Proceedings of the Jornada La Gestió de les Inundacions, Barcelona, Spain, 27-28 November 2013; pp. 120-125.

23. Confederación Hidrográfica del Ebro. Informe de la Avenida del 17 al 20 de Junio de 2013 en la Cuenca del río Garona (689/377); Confederación Hidrográfica del Ebro: Zaragoza, Spain, 2014.

24. Victoriano, A.; García-Silvestre, M.; Furdada, G.; Bordonau, J. Long-term entrenchment and consequences for present flood hazard in the Garona River (Val d'Aran, Central Pyrenees, Spain). Nat. Hazards Earth Syst. Sci. 2016, 16, 2055-2070. [CrossRef]

25. Knaepkens, G.; Bervoets, L.; Verheyen, E.; Eens, M. Relationship between population size and genetic diversity in endangered populations of the European bullhead (Cottus gobio): Implications for conservation. Biol. Conserv. 2004, 115, 403-410. [CrossRef]

26. Snyder, N.F.R.; Derrickson, S.R.; Beissinger, S.R.; Wiley, J.W.; Smith, T.B.; Toone, W.D.; Miller, B. Limitations of Captive Breeding in Endangered Species Recovery. Conserv. Biol. 1996, 10, 338-348. [CrossRef]

27. Robert, A. Captive breeding genetics and reintroduction success. Biol. Conserv. 2009, 142, $2915-2922$. [CrossRef]

28. McGowan, P.J.K.; Traylor-Holzer, K.; Leus, K. IUCN Guidelines for Determining When and How Ex Situ Management Should Be Used in Species Conservation. Conserv. Lett. 2016, 10, 361-366. [CrossRef]

29. Philippart, J.C. Is captive breeding an effective solution for the preservation of endemic species? Biol. Conserv. 1995, 72, 281-295. [CrossRef]

30. Dolman, P.M.; Collar, N.J.; Scotland, K.M.; Burnside, R.J. Ark or park: The need to predict relative effectiveness of ex situ and in situ conservation before attempting captive breeding. J. Appl. Ecol. 2015, 52, 841-850. [CrossRef]

31. Araki, H.; Cooper, B.; Blouin, M.S. Genetic Effects of Captive Breeding Cause a Rapid, Cumulative Fitness Decline in the Wild. Science 2007, 318, LP100-LP103. [CrossRef] [PubMed]

32. Griffiths, R.A.; Pavajeau, L. Captive Breeding, Reintroduction, and the Conservation of Amphibians. Conserv. Biol. 2008, 22, 852-861. [CrossRef] [PubMed]

33. Miller, E.J.; Eldridge, M.D.B.; Morris, K.; Thomas, N.; Herbert, C.A. Captive management and the maintenance of genetic diversity in a vulnerable marsupial, the greater bilby. Aust. Mammal. 2015, 37. [CrossRef]

34. ADEFFA. El cavilat. Conèixer-lo per conservar-lo [Documentary]; ADEFFA: Barcelona, Spain, 2016.

35. Thoen, E.; Evensen, Ø.; Skaar, I. Pathogenicity of Saprolegnia spp. to Atlantic salmon, Salmo salar L., eggs. J. Fish Dis. 2011, 34, 601-608. [CrossRef]

36. Vught, I.; De Charleroy, D.; Van Liefferinge, C.; Coenen, E.; Coeck, J. Conservation of bullhead Cottus perifretum in the Demer River (Belgium) basin using re?introduction. J. Appl. Ichthyol. 2011, 27, 60-65. [CrossRef]

37. Piccinini, A.; Bilò, F.; Stefani, L.; Marzano, F.N. Artificial breeding of bullhead Cottus gobio in two full recirculation systems. Ital. J. Freshw. Ichthyol. 2017, 1. Available online: http://www.aiiad.it/ijfi/index.php/ijfi/ article/view/35 (accessed on 19 June 2020).

38. Morris, D. The reproductive behaviour of the river bull-head (Cottus gobio L.), with special reference to the fanning activity. Behaviour 1954, 7, 1-32. [CrossRef]

39. Smith, S.; Armstrong, R.A.; Springate, J.; Barker, G. Infection and colonization of trout eggs by Saprolegniaceae. Trans. Br. Mycol. Soc. 1985, 85, 719-723. [CrossRef]

40. Khoo, L. Fungal diseases in fish. Semin. Avian Exot. Pet Med. 2000, 9, 102-111. [CrossRef]

41. Fregeneda-Grandes, J.M.; Rodríguez-Cadenas, F.; Aller-Gancedo, J.M. Fungi isolated from cultured eggs, alevins and broodfish of brown trout in a hatchery affected by saprolegniosis. J. Fish Biol. 2007, 71, 510-518. [CrossRef]

42. Bisazza, A.; Marconato, A. Female mate choice, male-male competition and parental care in the river bullhead, Cottus gobio L. (Pisces, Cottidae). Anim. Behav. 1988, 36, 1352-1360. [CrossRef] 
43. Marconato, A.; Bisazza, A. Mate choice, egg cannibalism and reproductive success in the river bullhead, Cottus gobio L. J. Fish Biol. 1988, 33, 905-916. [CrossRef]

44. Goto, A. Male mating success and female mate choice in the river sculpin, Cottus nozawae (Cottidae). Environ. Biol. Fishes 1993, 37, 347-353. [CrossRef]

45. Abdoli, A.; Pont, D.; Sagnes, P. Influence of female age, body size and environmental conditions on annual egg production of the bullhead. J. Fish. Biol. 2005, 67, 1327-1341. [CrossRef]

46. Natsumeda, T.; Mori, S.; Yuma, M. Size-mediated dominance and aggressive behavior of male Japanese fluvial sculpin Cottus pollux (Pisces: Cottidae) reduce nest-site abundance and mating success of conspecific rivals. J. Ethol. 2012, 30, 239-245. [CrossRef]

47. Shumway, C.A. A neglected science: Applying behavior to aquatic conservation. Environ. Biol. Fishes 1999, 55, 183-201. [CrossRef]

48. Brown, L. Patterns of female choice in mottled sculpins (Cottidae, teleostei). Anim. Behav. 1981, $29,375-382$. [CrossRef]

49. Teixeira, C.P.; De Azevedo, C.S.; Mendl, M.; Cipreste, C.F.; Young, R.J. Revisiting translocation and reintroduction programmes: The importance of considering stress. Anim. Behav. 2007, 73, 1-13. [CrossRef]

50. Raghavan, R.; Philip, S.; Ali, A.; Katwate, U.; Dahanukar, N. Fishery, biology, aquaculture and conservation of the threatened Asian Sun catfish. Rev. Fish Biol. Fish. 2016, 26, 169-180. [CrossRef]

51. Oláh, J.; Farkas, J. Effect of temperature, $\mathrm{pH}$, antibiotics, formalin and malachite green on the growth and survival of Saprolegnia and Achlya parastic on fish. Aquaculture 1978, 13, 273-288. [CrossRef]

52. Heikkinen, J.; Tiirola, M.; Mustonen, S.M.; Eskelinen, P.; Navia-Paldanius, D.; Von Wright, A. Suppression of Saprolegnia infections in rainbow trout (Oncorhynchus mykiss) eggs using protective bacteria and ultraviolet irradiation of the hatchery water. Aquac. Res. 2016, 47, 925-939. [CrossRef]

53. Martínez-Palacios, C.A.; Morte, J.C.; Tello-Ballinas, J.A.; Toledo-Cuevas, M.; Ross, L.G. The effects of saline environments on survival and growth of eggs and larvae of Chirostoma estor estor Jordan 1880 (Pisces: Atherinidae). Aquaculture 2004, 238, 509-522. [CrossRef]

54. Matthews, R.A. Ichthyophthirius multifiliis Fouquet and Ichthyophthiriosis in Freshwater Teleosts. Adv. Parasitol. 2005, 59, 159-241. [CrossRef] [PubMed]

55. Marconato, A.; Bisazza, A.; Fabris, M. The cost of parental care and egg cannibalism in the river bullhead, Cottus gobio L. (Pisces, Cottidae). Behav. Ecol. Sociobiol. 1993, 32, 229-237. [CrossRef]

56. Willis, K.; Willis, R.E. How many founders, how large a population? Zoo Biol. 2010, 29, 638-646. [CrossRef] [PubMed]

57. Valbuena-Ureña, E.; Soler-Membrives, A.; Steinfartz, S.; Alonso, M.; Carbonell, F.; Larios-Martín, R.; Obon, E.; Carranza, S. Getting off to a good start? Genetic evaluation of the ex situ conservation project of the Critically Endangered Montseny brook newt (Calotriton arnoldi). PeerJ 2017, 5, e3447. [CrossRef]

58. Duchesne, P.; Bernatchez, L. An analytical investigation of the dynamics of inbreeding in multi-generation supportive breeding. Conserv. Genet. 2002, 3, 45-58. [CrossRef]

59. Williams, S.E.; Hoffman, E.A. Minimizing genetic adaptation in captive breeding programs: A review. Biol. Conserv. 2009, 142, 2388-2400. [CrossRef]

60. Frankham, R. Genetics and conservation biology. Comptes Rendus Biol. 2003, 326, 22-29. [CrossRef]

Publisher's Note: MDPI stays neutral with regard to jurisdictional claims in published maps and institutional affiliations.

(C) 2020 by the authors. Licensee MDPI, Basel, Switzerland. This article is an open access article distributed under the terms and conditions of the Creative Commons Attribution (CC BY) license (http://creativecommons.org/licenses/by/4.0/). 